\title{
Comparative Leaf Anatomy of Grasses (Poaceae) in Faisalabad Region of Pakistan
}

\author{
Tanzila Rafique ${ }^{1}$, Mansoor Hameed ${ }^{2}$, Mehwish Naseer ${ }^{1}$, Rizwan Rafique ${ }^{3,5 *}$, \\ Rumana Sadiq ${ }^{1}$, Annam Zikrea ${ }^{1,}$ Sana Tehseen ${ }^{1}$, Muhammad Rafique Sajjad ${ }^{4}$ \\ ${ }^{1}$ Department of Botany, GC Women University, Faisalabad 38040, Pakistan \\ ${ }^{2}$ Department of Botany, University of Agriculture Faisalabad, Pakistan \\ ${ }^{3}$ PMAS Arid Agriculture University Rawalpindi, Pakistan \\ ${ }^{4}$ Soil and Water Conservation Research Institute Talagang Road Chakwal, Pakistan \\ ${ }^{5}$ IFAS, University of Florida USA
}

Received: 26 December 2020

Accepted: 22 April 2021

\begin{abstract}
Grasses are of great importance for sustainable food production in different ecosystems. Leaf anatomical studies of grasses are the indicator for adaptation of grasses in different areas of the world. The present research study was conducted to evaluate the diversity of leaf anatomical adaptations in different grass species from Faisalabad region in Pakistan. Thicker epidermis in Paspaledium flavidium, Setaria pumila and Eleusine indica is the adaptation to survive under water stressed environments such as drought and salinity. Larger cortical cell area in Setaria verticillate, Digitaria sanguinalis and Eleusine indica is a sign of their wide distribution in a variety of environmental conditions. Eragrostis tenella and Desmostachya bipinnata with significantly larger vascular bundle is the better adaption to a variety of environments. Different species of grasses showed variable responses in their anatomical characters. These variations help to evaluate the adaptation of grasses in varying climatic conditions and their ability to tolerate abiotic stress (i.e., drought and salinity) which are common in this region in natural habitats of grasses.
\end{abstract}

Keywords: leaf anatomy, grasses, sclerenchyma, bulliform cells

\section{Introduction}

Grasses belong to the family Poaceae or Graminae which is economically the most important family of flowering plants consisting of about 700 genera, 55 tribes and 11000 species [1]. Grasses are widespread in their distribution and occupy a wide range of habitats

*e-mail: rizwanrafiqueao@gmail.com as compared to other plants, such as tropical, subtropical, temperate, humid and warm climates [2]. They are economically the most important group of flowering plants on the earth's surface by providing more than half of protein and three quarters of energy for the human consumption [3]. They are also major source of food for domesticated animals and wildlife [4].

Grasses have a great potential to survive in varying environmental conditions because of their adaptive features according to the habitat [5]. Grasses are vital 
component of biodiversity because they provide habitat for many insect and bird species, maintain complicated food chains and food webs by acting as primary producers of ecosystem, increase land durability and fertility and control soil erosion [6].

Poaceae family shows great diversity in anatomical characteristics than any other family and gives valuable information about those anatomical characters that are important taxonomically [7]. Leaf anatomical characteristics such as leaf thickness, sclerification in leaves, trichomes, bulliform cells, presence of bundle sheath, number of vascular bundles, size of vascular tissue and stomatal size and density are quite responsive to different climatic conditions. Hence these characters can be considered as potential indicators of different environmental stress like drought and salinity $[8,9]$.

Pakistan has diverse climatic conditions ranging from semi humid and humid in north to dry and semi dry in west with wide range of variations in temperature and rainfall pattern. As population of Pakistan is increasing tremendously and its food resources are decreasing continuously at alarming stage [6]. Therefore, maintenance of natural ecosystem is becoming difficult by the day, and ensuring a sustainable ecosystem is in great jeopardy as climate directly effects on all plant characters [10]. Therefore, exploring natural grasses for their potential anatomical features are necessary to utilize vast natural diversity of family Poaceae for their suitability to support natural flora and fauna. Faisalabad is a highly industrialized city of Pakistan, with low rainfall and warm climatic conditions. Faisalabad is situated outside the tropics with altitude $184.4 \mathrm{~m}$, latitude $31^{\circ} 26$ and longitude $71^{\circ} 06$ [11]. The saline soil conditions of Faisalabad put increasing pressure on grass habitats. Therefore, present study was designed to explore the adaptability potential of family Poaceae in subtropical conditions of Faisalabad region.

\section{Material and Methods}

A comprehensive field survey was carried out in Faisalabad and its adjoining districts where frequent field visits were planned to collect leaf samples of different grass species for comparative leaf anatomical character evaluation. $1 \mathrm{~cm}$ leaf sample was taken from center along with the midrib and these samples were immediately preserved in formalin acetic acid alcohol (formalin 10\%, acetic acid 5\%, distilled water 35\% and ethyl alcohol 50\%) for 48 hours. Samples were then shifted to acetic alcohol solution (ethanol $75 \%$ and acetic acid $25 \%$ ) for permanent preservation.

For the preparation of permanent slides, thin sections of preserved plant material were obtained by free hand sectioning. Double stained technique (safranin and fast green) was used to study various leaf cells and tissues [12]. Anatomical photographs were taken with cameraequipped microscope (Nikon 104, Japan) and data was recorded for various parameters like leaf thickness, size of dermal tissue, vascular tissue, parenchymatous and mechanical tissue. The data recorded for various parameters were analyzed statistically by using ANOVA [13].

The following formula was used for the area calculation of different cells and tissues:

$$
\begin{gathered}
\text { Area }=\text { maximum length } \times \text { maximum width } \\
\qquad \times 22 / 28
\end{gathered}
$$

\section{Results}

Various leaf anatomical features were studied during the investigation. The analysis of variance regarding midrib thickness showed that significant differences exist among different species of grasses. Maximum midrib thickness was observed in Setaria verticillate, Setaria viridis, Paspaledium flavidium and Setaria pumila. Comparatively less midrib thickness was noticed in Leptochloa fascicularis and Leptochloa panicea. Desmostachya bipinnata showed maximum lamina thickness followed by Eragrostis tenella and Paspaledium flavidium. Minimum value of lamina thickness was found in Leptochloa panicea while other species showed no significant difference. Maximum adaxial epidermis thickness was observed in Echinocloa clona closely followed by Paspaledium flavidium, Eleucine indica and Paspalum longifolium. A significant increase in abaxial epidermis thickness was observed in Paspaledium flavidium while remaining species showed variation in this character (Fig. 1).

Statistical analysis revealed that significant variations exist in cortex thickness of different grasses. Setaria viridis showed comparatively higher cortex thickness while cortex thickness was minimum in Leptochloa panicea, Eragrostis minor and Eragrostis tenella. The highest value of cortical cell area was noticed in Setaria verticillate, Digitaria sanguinalis and Eleusine indica. Smallest value of cortical cell area was observed in Leptochloa panicea, Eragrostis tenella (Fig. 2).

Sclerenchyma thickness also showed significant variation in different species of grasses. The maximum value of sclerenchyma thickness was revealed in Desmostachya bipinnata while minimum value of sclerenchyma thickness was observed in Dactyloctenium aegyptium and Digitaria sanguinalis. Data regarding bundle sheath area showed highest value in Eragrostis tenella followed by Eleusine indica. In the remaining species significant difference was not observed.(Fig. 2).

Epidermal cell area on both adaxial and abaxial surface was observed maximum in Paspaledium flavidium and Setaria pumila and minimum in Imperata cylindrica, Panicum antidotale and Desmostachya bipinnata. Vascular bundle area showed a significant increase in Eragrostis tenella and Desmostachya bipinnata and significant decrease was recorded in Digitaria adscendens, Eragrostis minor, Leptochloa 
Table 1. List of some species of grasses used for leaf anatomical studies from the Faisalabad region.

\begin{tabular}{|c|c|c|c|}
\hline Sr. No & Species & Vernacular Name & Place of collection \\
\hline 1 & Cenchrus setigerus & Birdwood grass & PFRI, Gatwala \\
\hline 2 & Cenchrus pennisetiformis & Buffel grass & PFRI, Gatwala \\
\hline 3 & Digitaria sanguinalis & Hairy finger-grass & UA, Faisalabad \\
\hline 4 & Digitaria adscendens & Tropical crabgrass & PFRI, Gatwala \\
\hline 5 & Setaria verticillata & Hooked bristle grass & UA, Faisalabad \\
\hline 6 & Setaria viridis & Green bristle grass & UA, Faisalabad \\
\hline 7 & Setaria pumila & Cattail grass & UA, Faisalabad \\
\hline 8 & Paspalum paspaloides & Knotgrass & PFRI, Gatwala \\
\hline 9 & Paspalidium flavidum & Yellow water crown grass & PFRI, Gatwala \\
\hline 10 & Imperata cylindrica & Cogon grass & UA, Faisalabad \\
\hline 11 & Sorghum halepense & Johnson grass & UA, Faisalabad \\
\hline 12 & Leptochloa panicea & Thread sprangletop & Satiana \\
\hline 13 & Echinochloa colona & Jungle rice & Satiana \\
\hline 14 & Eleusine indica & Goose grass & Samundri \\
\hline 15 & Dactyloctenium aegyptium & Crowfoot grass & Tandlianwala \\
\hline 16 & Panicum antidotale & Blue panic grass & Tandlianwala \\
\hline 17 & Dichanthium annulatum & Kleberg bluestem & PFRI, Gatwala \\
\hline 18 & Eragrostis tenella & Bug's egg grass & UA, Faisalabad \\
\hline 19 & Paspalum longifolium & Paspalum & UA, Faisalabad \\
\hline 20 & Desmostachya bipinnata & Halfa grass & UA, Faisalabad \\
\hline 21 & Eragrostis minor & Cane grass & Dijkot \\
\hline 22 & Leptochloa fascicularis & Bearded sprangletop & Dijkot \\
\hline
\end{tabular}

Punjab Foresty Research Institute (PFRI), Gatwala, University of Agriculture (UA), Faisalabad

panicea and Leptochloa fascicularis. The significantly higher metaxylem area was recorded in Eragrostis tenella. Minimum value of this character was observed in Leptochloa panicea, Digitaria adscendens and Imperata cylindrica (Fig. 3). Maximum phloem area was noted in Desmostachya bipinnata while minimum value of this character was found in Eragrostis minor, Paspalum flavidium, Setaria viridis, Digitaria adscendens and Digitaria sanguinalis (Fig. 4).

Higher bulliform cell area was noticed in Eragrostis tenella while minimum bulliform cell area was observed in Panicum antidotale, Cenchrus pennisetiformis, Imperata cylindrica and Cenchrus setigerus. In the remaining species there is no significant difference in the bulliform cell area (Fig. 4).

\section{Discussion}

The study of anatomical traits is of great significance for taxonomists and ecologists as it provides all the necessary information to resolve the problem of closely related species and their adaptive characters in different regions of world. Plant anatomical features mainly varied according to environmental conditions [14]. The results of the present study highlight anatomical variations in different grass species which enable them to survive in varying environmental conditions.

Thick epidermis is a valuable trait in checking water loss during limited moisture availability [15]. Thick epidermis was observed in Paspaledium flavidium, Setaria pumila and Eleusine indica indicating that these species have better adaptability potential to survive under drought and salinity by playing a significant role in evapo-transpirational loss through leaf surface [16]. The results of the present investigation are according to many earlier studies $[15,17]$. Thick epidermis act as a barrier for preventing water loss thus help in water conservation $[18,19]$ hence grasses can survive under stress condition as well. An increase in epidermal thickness has been reported due to increased salinity in 

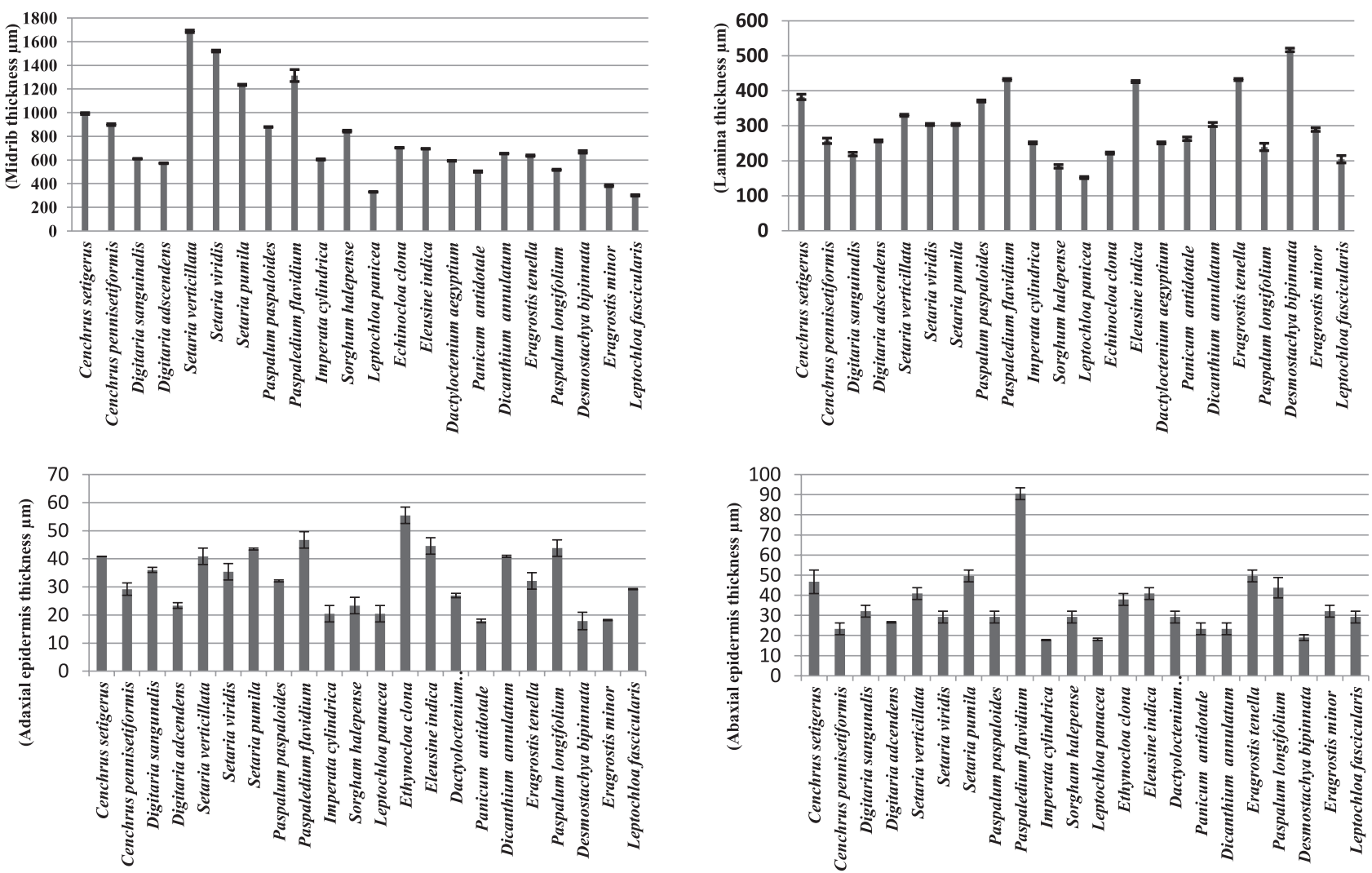

Fig. 1. Leaf anatomical characteristics of some species of family Poaceae from Faisalabad region.
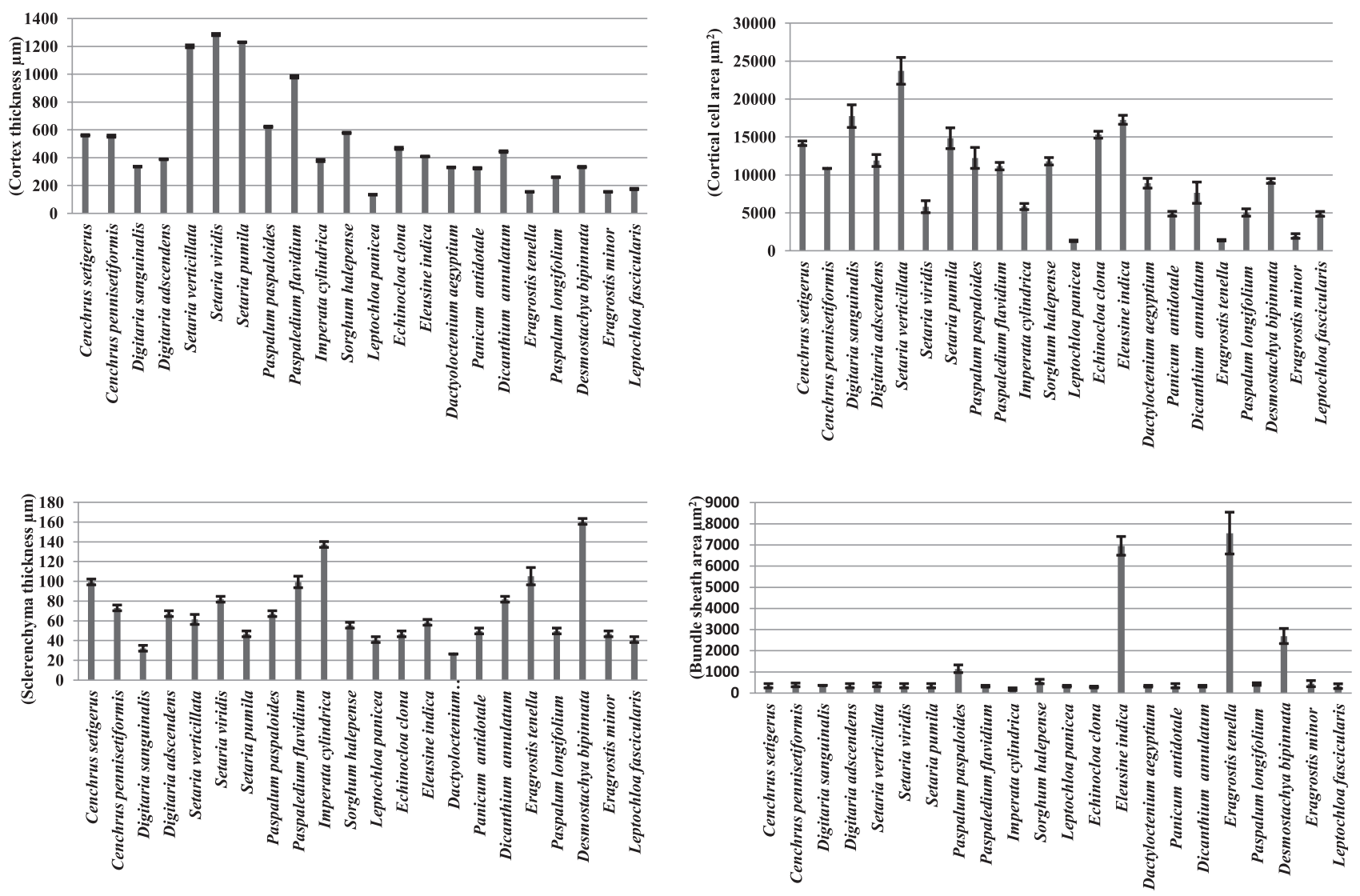

Fig. 2. Leaf anatomical characteristics of some species of family Poaceae from Faisalabad region. 
Ziziphus cultivars [20]. Leaf thickness is also helpful in storing water due to the succulent structure of leaf [21]. In the present study this feature was more prominent in Setaria verticillata, Paspaledium flavidium and Setaria viridis. This significant feature plays vital role in the survival of grass species residing in different environmental conditions [22].

Leaves have direct exposure to external environments therefore they are more responsive to different abiotic stresses than any other plant organ. [23]. Maximum midrib thickness was observed in
Setaria verticillate, Setaria viridis, that is due to increased proportion of cortical tissue. Cortical tissue in leaf performs the function of water storage under unfavorable environmental conditions [24] thus larger cortical cell area helps the plant to survive during harsh climatic conditions by storing water [25]. Maximum cortical cell area was noted in Setaria verticillate, Digitaria sanguinalis and Eleusine indica that indicates their better adaptability in a varying environmental condition especially in drought [26]. Increased sclerenchyma thickness in leaves provides
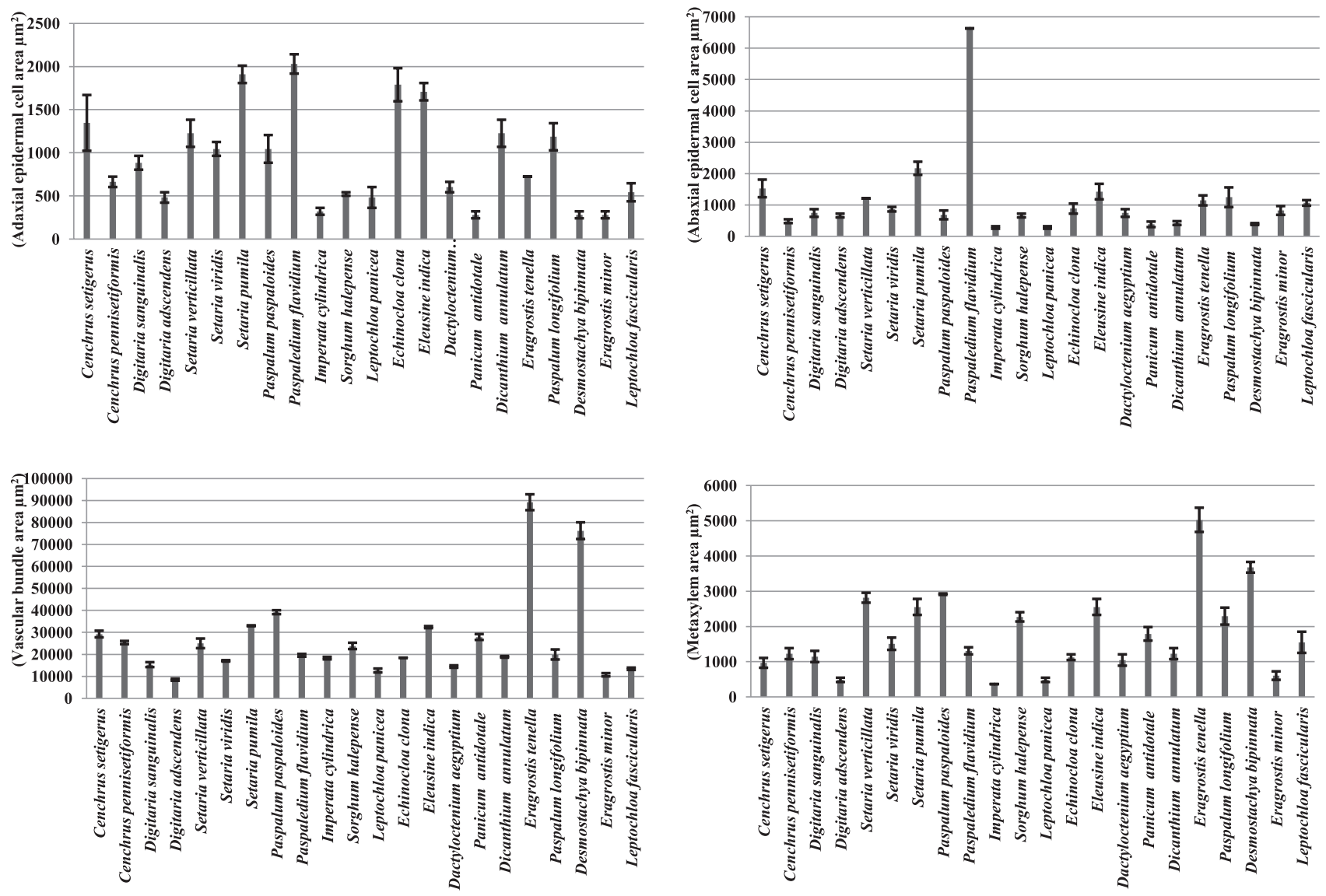

Fig.3. Leaf anatomical characteristics of some species of family Poaceae from Faisalabad region
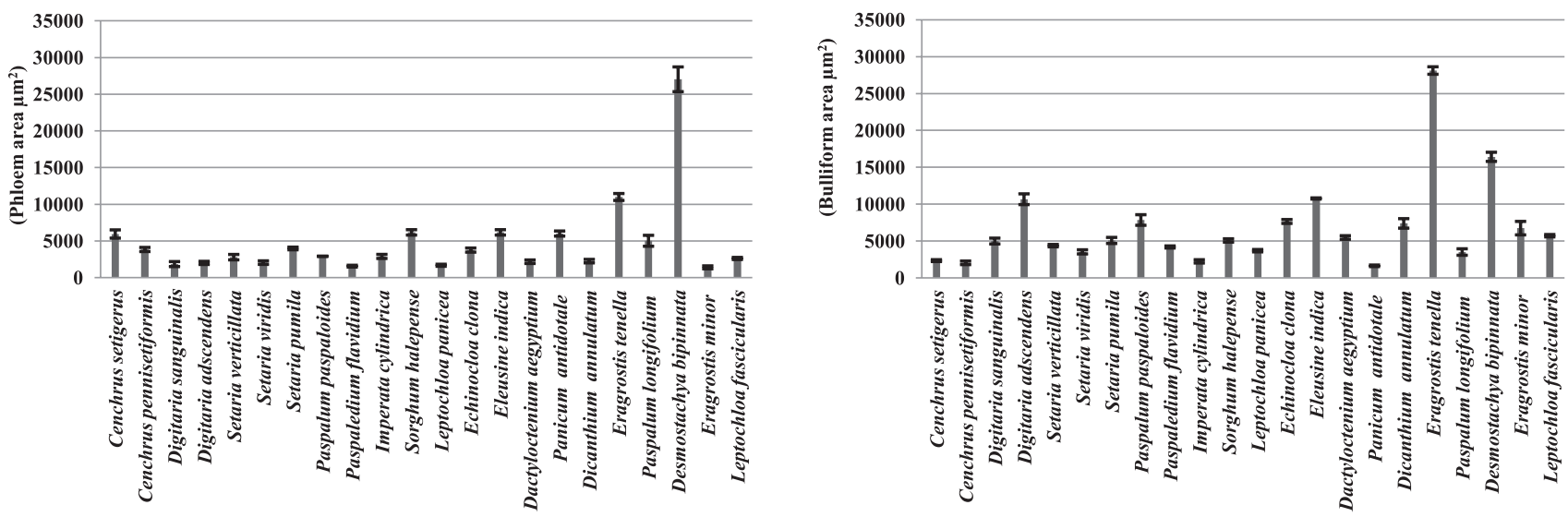

Fig. 4. Leaf anatomical characteristics of some species of family Poaceae from Faisalabad region. 
resistance to water loss by playing a key role in water conservation [27] and gives strength and protection to plant tissues [28]. Maximum sclerenchyma thickness in Desmostachya bipinnata and Imperata cylindrica are expected to be adapted to adverse environmental conditions and prevents soft tissue from collapsing [29]. It has been reported that increased sclerification is an important feature of most salt tolerant species including Aeluropus lagopoides [30, 31].

The bundle sheath cells play a key role in $\mathrm{CO}_{2}$ conductance because larger bundle sheath cells assist in increasing photosynthesis and hence improve salt tolerance. In the present study maximum bundle sheath area was recorded in Eragrostis tenella and Eleusine indica. Such adaptations were considered of significant importance and already observed in Spartina alterniflora [32]. Similar results were reported in Cynodon dactylon collected from Salt Range in Pothwar region of Pakistan where more bundle sheath thickness was observed in higher salinity level [33]. Vascular bundles are the crucial component of plant anatomy as they directly related to efficient transport

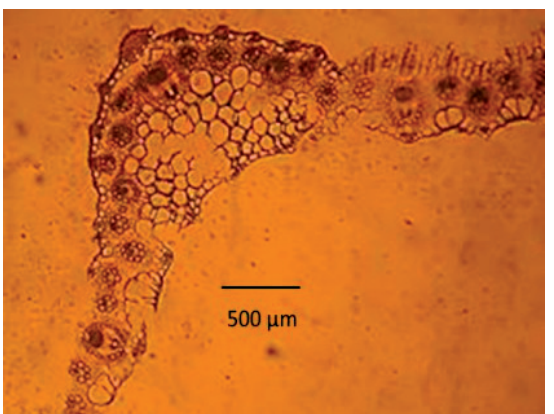

Cenchrus setigerus

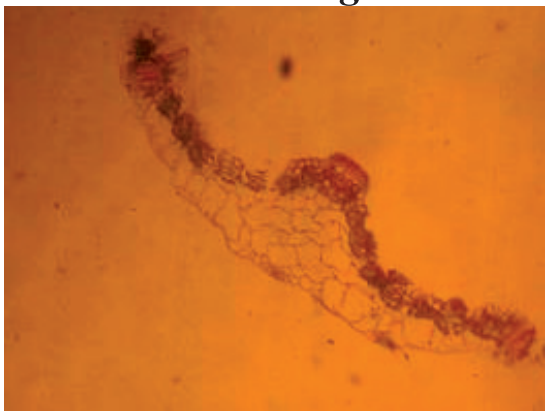

Digitaria adcendens

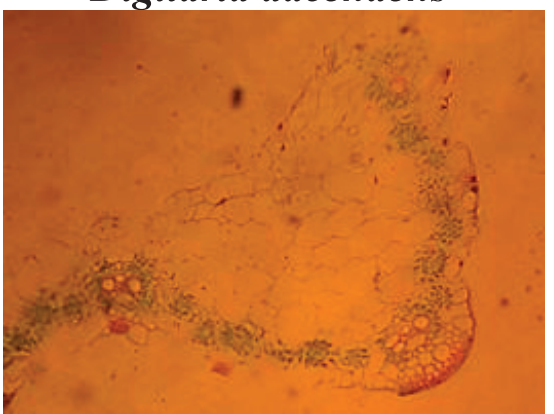

Setaria pumila

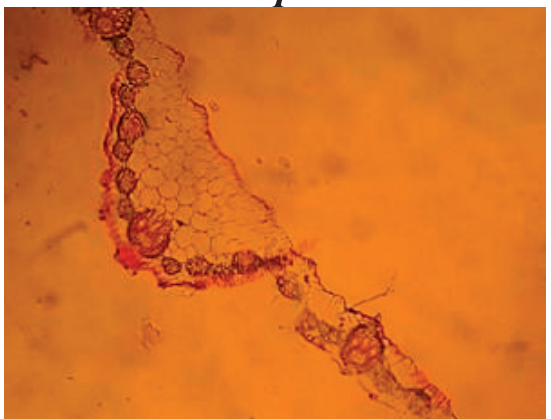

Imperata cylindrica

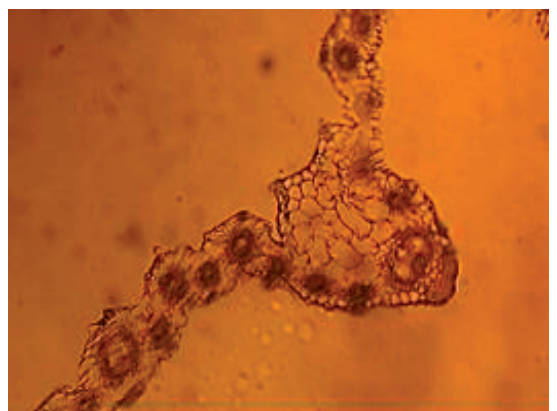

\section{Cenchrus pennisetiformis}

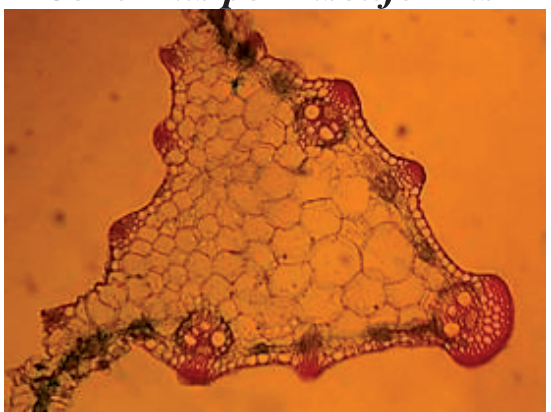

Setaria verticillata

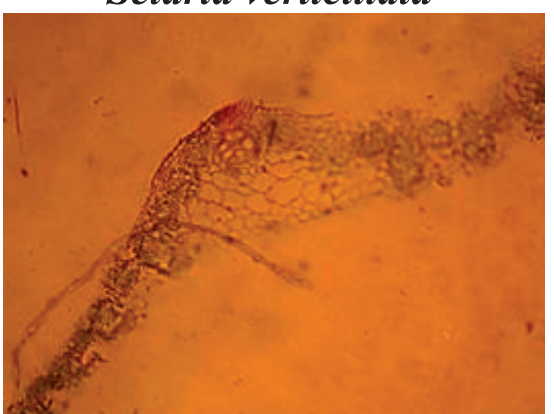

Paspalum paspaloides

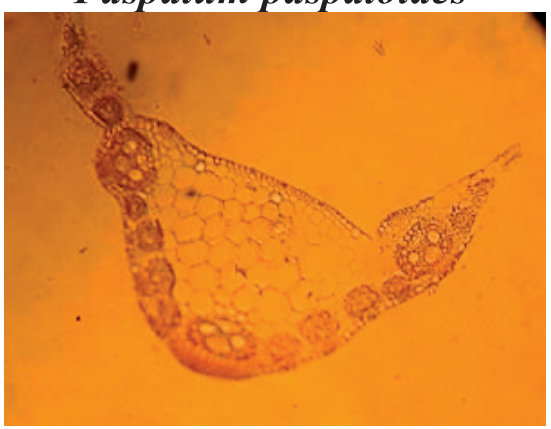

Sorgham halepense

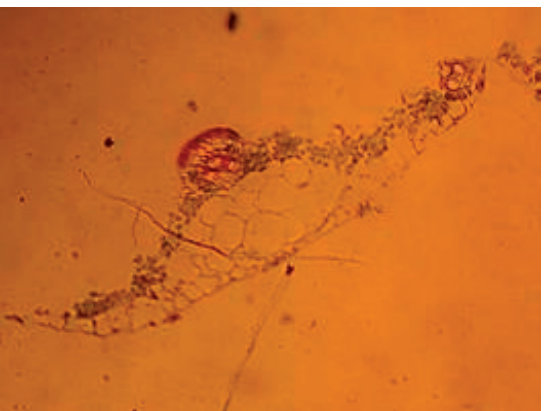

Digitaria sangunalis

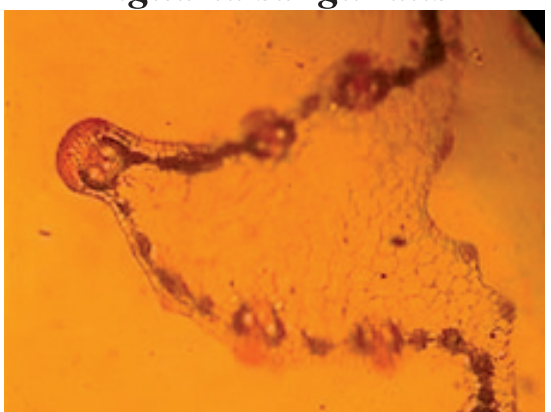

Setaria viridis

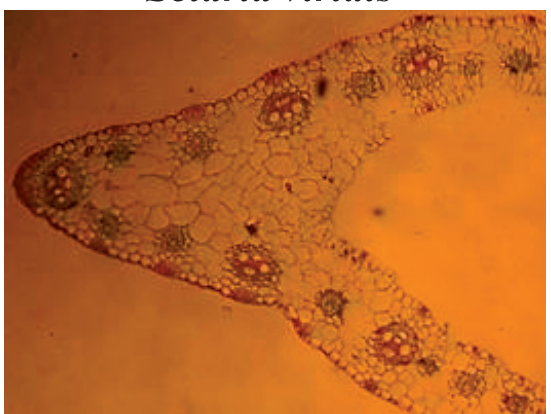

Paspaledium flavidium

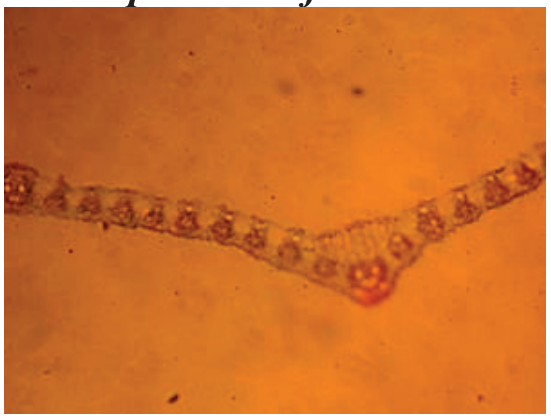

Leptochloa panicea

Fig. 5. Transverse section of leaf anatomical characteristics of some grasses from the Faisalabad region. 


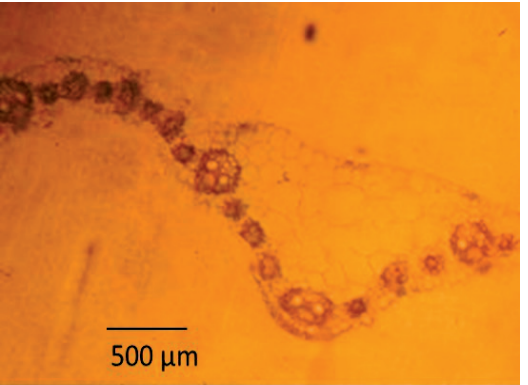

Echinochloa colona

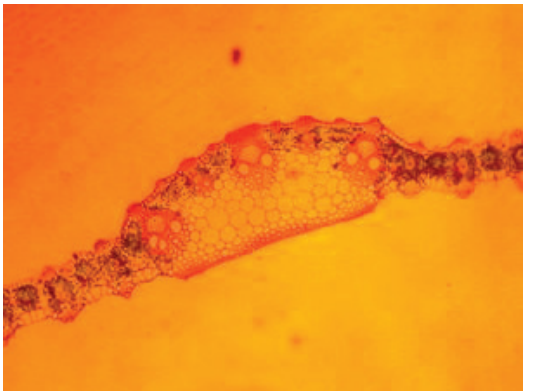

Panicum antidotale

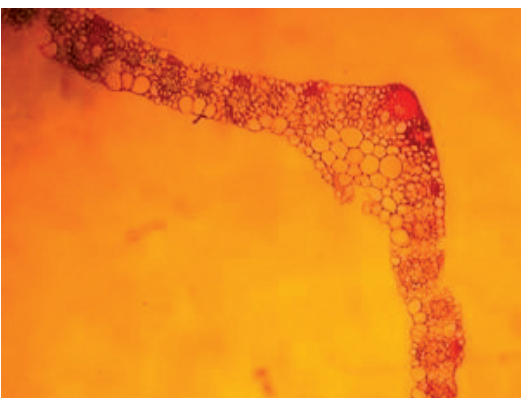

Paspalum longifolium

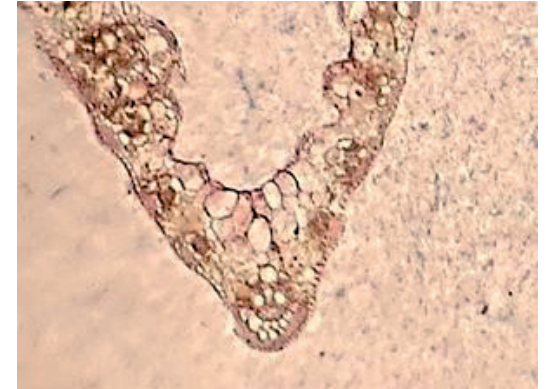

Eleusine indica

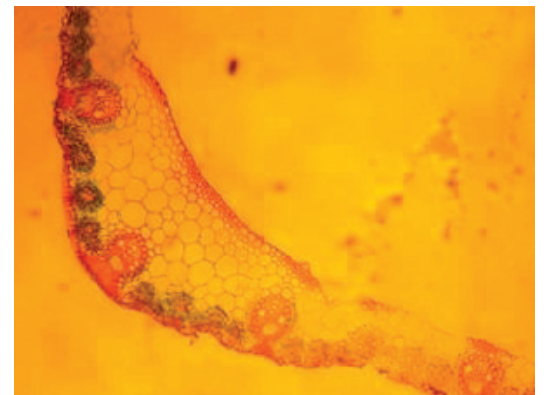

Dicanthium annulatum

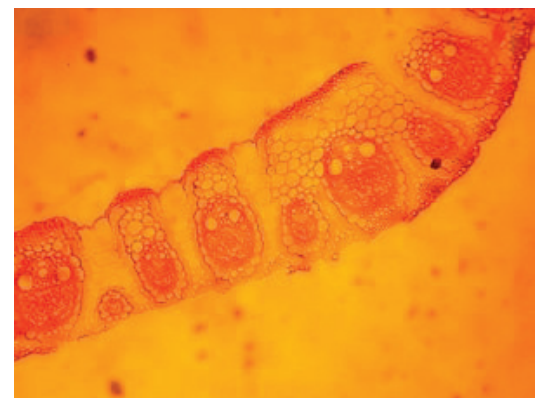

Desmostachya bipinnata

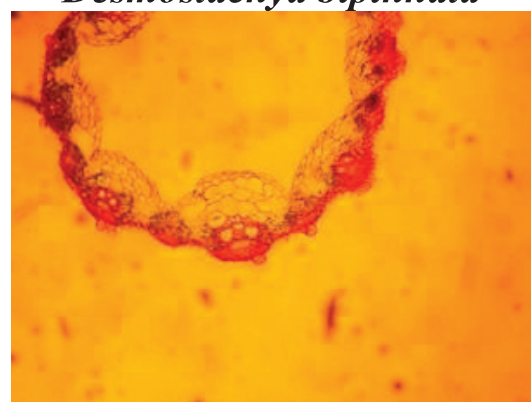

Leptochloa fascicularis
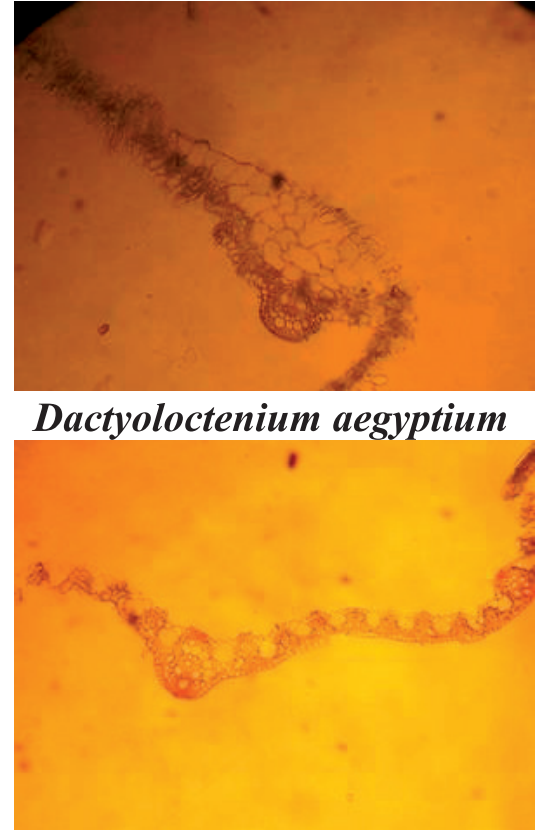

Eragrostis tenella



Eragrostis minor

Fig. 6. Transverse section of leaf anatomical characteristics of some grasses from the Faisalabad region.

of water and nutrients from the soil and considered of great importance under low moisture availability [34]. Any fluctuation in their number or area could minimize the conduction of photosynthates and solutes [35]. Large sized vascular bundle was observed in some saline tolerant genotypes of Ziziphus species [20]. Lager vascular bundle particularly with large metaxylem vessels in Eragrostis tenella and Desmostachya bipinnata is the crucial adaption to water stressed conditions and responsible for better conduction of water and nutrients [36].

Well-developed bulliform cells in the upper epidermis play a significant role in water conservation as these cells are involved in leaf rolling under drought conditions [37, 38]. Bulliform cells reduce the rate of light absorption and transpiration by minimizing direct stomatal exposure to external environments and these are found in many plant families such as Poaceae, Juncaceae and Cyperaceae [39]. The present study showed variation in the bulliform cells and maximum bulliform cell area was noticed in Eragrostis tenella and Desmostachya bipinnata. Such type of adaptations is assumed to reduce transpirational water loss through leaf surface [40, 41]. Leaf rolling in Imperata cylindrica was studied by at higher drought and salinity conditions [8]. 


\section{Conclusion}

This study has determined that wide leaf anatomical variations exist among different grass species under subtropical conditions of Faisalabad region. Different adaptive anatomical characters such as increased epidermis thickness, increased sclerenchyma thicknesses, leaf succulence, sclerification in the vascular bundles and presence of well-developed bulliform cells are considered important for their better survival under stress conditions i.e., drought, heat, salinity etc. Natural biodiversity found among grass species are highly valuable as they provide distinct character which help adopt them in different regions. Overall, all the grass species showed variation in leaf anatomy and such studies provide remarkable information about the characteristics of grasses and their diverse ecological range in different regions.

\section{Ethical Issues}

There are no ethical issues associated with this publication.

\section{Authors Contribution}

All authors have contributed equally and there is no conflict of interest.

\section{Acknowledgements}

Authors highly acknowledge University of Agriculture Faisalabad for the provision of resources and Lab facilities to complete this study.

\section{References}

1. CHEN S., SUN L. B., LIU L., WU Z., LU S., LI D., WANG Z., ZHU Z., XIA N. Poaceae (Gramineae). Flora of China. 22, 1, 2006.

2. MARSHALL V.M., LEWIS M.M., OSTENDORF B. Buffel grass (Cenchrus ciliaris) as an invader and threat to biodiversity in arid environments. J. Arid Environ. 78, $1,2012$.

3. CHRISTENHUSZ M.J.M., BYNG J.W. The number of known plants species in the world and its annual increase. Phytotaxa-Magnolia Press. 261, 201, 2016.

4. KHODARAHMPOUR Z. Effect of drought stress induced by polyethylene glycol (PEG) on germination indices in corn (Zea mays L.) hybrids. Afr. J. Biotechnol. 10, 18222, 2011.

5. FATIMA S., AHMAD F., HAMEED M., AHMAD R. Ecology and species association of grass species in response to altitudinal gradient in the Potohar region. Pak. J. Bot. 50, 41, 2018.

6. HUSAIN T., AHMED M., HUSSAIN A., NAZIM K. Effect of climatic change scenerio on reproductive behaviour of some fodder grasses growing wild in Pakistan. Fuuast J. Biol. 2, 85, 2012.

7. SHAHEEN S., AHMAD M., KHAN F., ZAFAR M., HUSSAIN R.A, RANI S., KHALID Z., AYUB R., YOUNIS A. Elemental dispersive spectrophotometer analysis and morpho-anatomical characterization of Panicum species from Pakistan. J. Med. Plants Res. 6, 1707, 2012.

8. HAMEED M., ASHRAF M., NAZ N. Anatomical adaptations to salinity in cogon grass Imperata cylindrica from the Salt Range, Pakistan. Plant Soil, 322, 2009.

9. SEVIK H., CETIN M., OZEL B., ERBEK A., CETIN I.Z. The effect of climate on leaf micromorphological characteristics in some broad-leaved species. Environ. Dev. Sustain. 2, 13, 2020.

10. CETIN M., SEVIK H., YIGIT N. Climate type-related changes in the leaf micromorphological characters of certain landscape plants. Environ. Monit. Assess. 190, 404, 2018.

11. CHEEMA M.A., FAROOQ M.U., AHMAD R.A., MUNIR H.A. Climatic trends in Faisalabad (Pakistan) over the last 60 years (1945-2004). J. Agric. Social Sci. 2, 42, 2006.

12. RUZIN S.E. Plant Microtechnique and Microscopy. Oxford Univ. Pres, New York. 1999.

13. STEEL R.G.D., TORRIE J.H. Principles and procedures of statistics, with special reference to biological sciences. McGraw Hill Book Co., Inc., New York. 1984.

14. MENG L., MAO P. Micromorphological and anatomical features of four species of Elytrigia Desv. (Poaceae). Bangladesh J. Plant Taxon. 20, 135, 2013.

15. LIU Y., LI X., CHEN G., LI M., LIU M., LIU D. Epidermal micromorphology and mesophyll structure of Populus euphratica heteromorphic leaves at different development stages. PloS One. 10, 9, 2015.

16. KHAN N., BANO A., BABAR M.A. The root growth of wheat plants, the water conservation and fertility status of sandy soils influenced by plant growth promoting rhizobacteria. Symbiosis. 72, 195, 2017.

17. FANG Y., XIONG L. General mechanism of drought. General mechanism of drought response and their application in drought resistance improvement in plants. Cell Mol. Life Sci. 38, 673, 2015

18. DE MICCO V., ARONNE G. Morpho-anatomical traits for plant adaptation to drought. Plant Responses to Drought Stress. Springer, Berlin, Heidelberg, 37-61, 2012.

19. JIANJING M.A., CHENGJUN J.I., MEI H., TINGFANG Z., XUEDONG., DONG H., HUI Z., JINSHENG H. Comparative analysis of leaf anatomy of dicotyledonous species in Tibetan and Inner Mongolian grassland. China Life Sci. 55, 68, 2012.

20. AWASTHI O.P., PATHAK R.K., PANDEY S.D. Anatomical variation in leaf lamina of ber seedling and budded plants grown at different sodicity levels. Indian J. Hort. 56, 29, 1999.

21. WASIM M.A., NAZ N. Anatomical adaptations of tolerance to salt stress in Cenchrus ciliaris L., a saline desert grass. J. Anim. Plant Sci. 30, 1548, 2020.

22. BUGHIO F.A., MANGRIO S.M., ABRO S.A, JAHANGIR T.M., BUX H. Physio-morphological responses of native Acacia nilotica to eucalyptus allelopathy. Pak. J. Bot. 45, 97, 2013.

23. DRAKE P.L., DE BOER H.J., SCHYMANSKI S.J., VENEKLAAS E.J. Two sides to every leaf: water and CO 2 transport in hypostomatous and amphistomatous leaves. New Phytologist, 222 (3), 1179, 2019. 
24. AZUMA W., ISHII H. R., KURODA K. Function and structure of leaves contributing to increasing water storage with height in the tallest Cryptomeria japonica trees of Japan. Trees, 30, 141, 2016.

25. KASHIWAGI J., KRISHNAMUTHY L., PURUSHOTHAMAN R., UPADHYAYA H.D., GAUR P.M., GOWDA C.L.L., VARSHANEY R.K. Scope for improvement of yield under drought through the root trait in chickpea (Cicer arietinum L.) Field Crop Res. 170, 47, 2015.

26. PEREIRA L.A.R., PINA G.O., SILVEIRA C.E.S., GOMES S.M, TOLEDO J.L. Effects of Eugenia dysenterica L. extracts on roots and gravitropism of Sesamum indicum L. and Raphanus sativus L. Allelopathy J. 42, 3, 2017.

27. NAWAZ T., HAMEED M., ASHRAF M., BATOOL S., NAZ N. Modifications in root and stem anatomy for water conservation in some diverse blue panic (Panicum antidotale Retz.) ecotypes under drought stress. Arid Land Res. Manag. 27, 286, 2013.

28. ELANSARY H.O., SKALICKA K., KING I.W. Enhancing stress growth traits as well as phytochemical and antioxidant contents of Spiraea and Pittosporum under seaweed extract treatments. J. Plant Physiol. Biochem. 105, 310, 2016.

29. AL-MASKRI A., HAMEED M., KHAN M.M. Morphological characterization and structural features for high drought tolerance in some Omani wheat landraces. Int. Conf. Food Agric. Sci. 55, 23, 2013.

30. HAMEED M., NAWAZ T., ASHRAF M., TUFAIL M., KANWAL H., AHMAD M.S.A., AHMAD I. Leaf anatomical adaptations of some halophytic and xerophytic sedges of the Punjab. Pak. J. Bot. 44, 159, 2012.

31. NAZ N., HAMEED M., NAWAZ T., BATOOL R., ASHRAF M., AHMAD F., RUBY T. Structural adaptations in the desert halophyte Aeluropus lagopoides (Linn.) Trin. ex Thw. under high salinity. J. Biol. Res. 19, 150, 2013.

32. WALSH G.E. Anatomy of the seed and seedling of Spartina alterniflora Lois. (Poaceae). Aquat. Bot. 38, 177, 1990.
33. HAMEED M., ASHRAF M., NAZ N., NAWAZ T., BATOOL R., AHMAD M.S.A., AHMAD F., HUSSAIN M. Anatomical adaptations of cynodon dactylon (1.) Pers. from the salt range (Pakistan) to salinity stress, Leaf anatomy. Pak. J. Bot. 45, 133, 2013.

34. MANSOOR U., FATIMA S., HAMEED M., NASEER M., AHMAD M.S, ASHRAF M., AHMAD F., WASEEM M. Structural modifications for drought tolerance in stem and leaves of Cenchrus ciliaris L. ecotypes from the Cholistan Desert. Flora. 261, 1, 2019.

35. ZHAOSEN X., FORNEY C.F., HONGMEI C., LI B. Changes in water translocation in the vascular tissue of grape during fruit development. Pak. J. Bot. 46, 483, 2014.

36. NASEER M., HAMEED M., ZAHOOR A., AHMAD F., FATIMA S., AHMAD M.S.A., IFTIKHAR M. Photosynthetic response in buttonwood (Conocarpus erectus L.) to salt stress. Pak. J. Bot. 49, 847, 2017.

37. SAGLAM A., KADIOGLU A., DEMIRALAY M., TERZI $\mathrm{R}$. Leaf rolling reduces photosynthetic loss in maize under severe drought. Acta Bot. Croat.73, 315, 2014.

38. NAIDOO L., CHO M.A., MATHIEU R., ASNER G. Classificationof savanna tree species, in the Greater Kruger National Park region, by integrating hyperspectral and LiDAR data in a Random Forest data mining environment. J. Photogramm. 9, 617, 2012.

39. GRIGORE M.N., TOMA C. Bulliform cells. In: Anatomical Adaptations of Halophytes. Springer, Cham, Switzerland. pp. 325-338, 2017.

40. WANG X., JIANG C., SZETO Y.T., LI H.K., YAM K.I. Effects of Dracontomelon duperreanum defoliation extract on Microcystis aeruginosa: physiological and morphological aspects. Environ. Sci. Pollut. Res. 23, 8731, 2016.

41. URBAN J., INGWERS M., MCGUIRE M.A., TESKEY R.O. Stomatal conductance increases with rising temperature. Plant Signal. Behav. 12, 1356534, 2017. 
